\title{
Effect of Silicon through Potassium Silicate on Yield, Nutrient Uptake and Quality of Grand Naine Banana
}

\author{
Arthi Vijayan, ${ }^{1}$ M.V. Sriramachandrasekharan ${ }^{2 *}$, R. Manivannan ${ }^{3}$ and Arumugam Shakila ${ }^{4}$ \\ ${ }^{1}$ Department of Soil Science and Agricultural Chemistry, Faculty of Agriculture, Annamalai University \\ Annamalainagar, Tamilnadu, India \\ Email: arthivijayan6 [AT] gmail.com \\ ${ }^{2}$ Department of Soil Science and Agricultural Chemistry, Faculty of Agriculture, Annamalai University \\ Annamalainagar, Tamilnadu, India \\ *Corresponding author's email: ram_uthrat [AT] yahoo.com \\ ${ }^{3}$ Department of Soil Science and Agricultural Chemistry, Faculty of Agriculture, Annamalai University \\ Annamalainagar, Tamilnadu, India \\ Email: rengamanivannan [AT] gmail.com \\ ${ }^{4}$ Department of Horticulture, Faculty of Agriculture, Annamalai University \\ Annamalainagar, Tamilnadu, India \\ Email: kiransharaj [AT] gmail.com
}

\begin{abstract}
Field experiment was conducted in Farmers holding located at Rajagopalapuram village under Kuttalam taluk, Mayiladuthurai district, Tamilnadu, India belonging to Padugai series (Typic ustifluvent) low in available silicon to elucidate the response of banana in terms of yield, nutrition and quality due to silicon nutrition

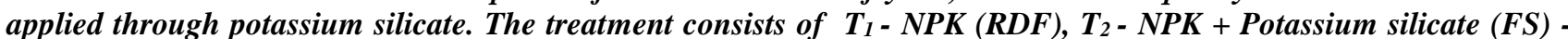
$0.25 \%, \mathrm{~T}_{3}-\mathrm{NPK}+$ Potassium silicate $(\mathrm{FS})-0.50 \%, \mathrm{~T}_{4}-\mathrm{NPK}+$ Potassium silicate $(\mathrm{FS})-1.00 \%, \mathrm{~T}_{5}-\mathrm{NPK}+\mathrm{Potassium}$ silicate (FS) - 0.25\%, T6- NPK + Potassium silicate (FS) - 0.50\%, T7- NPK + Potassium silicate (FS) - 1.00\%, T8 - NPK + Potassium silicate (SA) - $50 \mathrm{~kg} \mathrm{ha}^{-1}, \mathrm{~T}_{9}-\mathrm{NPK}+$ Potassium silicate $(\mathrm{SA})-100 \mathrm{~kg} \mathrm{ha}^{-1}$ and $\mathrm{T}_{10}-\mathrm{NPK}+\mathrm{Potassium}$ silicate $(S A)-150 \mathrm{~kg} \mathrm{ha}^{-1}$. From $\mathrm{T}_{2}$ to $\mathrm{T}_{4}$ foliar spray was done at $3^{\text {rd }}$ and $5^{\text {th }}$ month and from $\mathrm{T}_{5}$ to $\mathrm{T}_{7}$, foliar spray was done at $3^{\text {rd }}$, $5^{\text {th }}$ and $7^{\text {th }}$ month. The test crop is Banana Var. Grand Naine. The results showed that the highest fruit yield was noticed with $50 \mathrm{~kg} \mathrm{Si} \mathrm{ha}^{-1}(96.0 \mathrm{t} \mathrm{ha-1})$ and it reduced with Si levels. Among foliar treatments, fruit yield increased with silicon concentrations $(0.25$ to $1 \%)$. The highest fruit yield was observed with $1 \%$ Si applied at $3^{\text {rd }}$ and $5^{\text {th }}$ month $\left(92.7 \mathrm{tha}^{-1}\right)$. Foliar spray of 0.25 and $0.5 \%$ Si applied thrice increased the fruit yield compared to twice application at same concentration. But fruit yield declined when Si was sprayed at $1 \%$ thrice. Soil application of silicon recorded higher nutrient uptake over foliar addition. The nutrient uptake was maximum with $150 \mathrm{~kg} \mathrm{Si} \mathrm{ha-1.} \mathrm{With} \mathrm{respect} \mathrm{to}$ foliar treatments, the highest uptake was noticed with foliar spray of $1 \%$ Si applied at $3^{\text {rd }}$ and $5^{\text {th }}$ month. Soil application

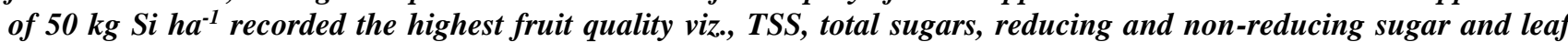
protein. The highest fruit quality was noticed with foliar spray of 1\% Si applied at 3rd and 5th month.
\end{abstract}

Keywords--- silicon, banana yield, quality, uptake

\section{I.INTRODUCTION}

Silicon is the most abundant element in the earth's crust region next to oxygen and comprises $28 \%$ of its weight, $3-17 \%$ in soil solution (Epstein, 1999). Silicon is mostly commonly found in soils in the form of solution as silicic acid $\left(\mathrm{H}_{2} \mathrm{SiO} 2\right)$ and plants take up directly as silicic acid [16]. Silicon concentration in plants offers a large variability ranging from 0.1 to 10 per cent dry weight depending upon species [5 \& 9]. Silicon has a key role in plant environment relationship because it can improve plant abilities to withstand edaphic climatic and/ or biological adversities by acting as a "Natural antistress" mechanism that enables higher yields and better quality end product [4 \& 25]. Adequate nutrition of silicon interferes in the plant architecture by providing more erect leaves, increasing solar radiation interception and photosynthetic efficiency [24 \& 2]. The ability of silicon accumulation in tissue varies among species which may be classified into accumulator $(>4 \%$ $\mathrm{Si})$ intermediate $(2-4 \% \mathrm{Si})$ and non-accumulator of $\mathrm{Si}(<2 \% \mathrm{Si})$ [15]. Silicon can be applied to plants directly to the leaves (foliar spray) or in granular form which is incorporated into soil before planting. Methods of fertilizer application have modifying effects on Si plant growth [18].

Banana botanically belongs to family Musasceae. It contains about $74 \%$ water, $23 \%$ carbohydrate, $1 \%$ protein and $0.5 \%$ fat and also a source of vitamins. Banana is the fifth largest agricultural commodity in the world trade after cereals, sugar, coffee and cocoa and second largest fruit crop in the world. Tamilnadu has the largest area of 0.12 Mha and the 
production of $0.82 \mathrm{MT}$ and productivity of $52.5 \mathrm{mt} / \mathrm{ha}$ [22]. Banana owing to its large size and rapid growth rate require relatively larger amount of nutrients for high yields of quality fruits. Little is known of silicon in banana. Silicon concentration in young plants ranges from 0.7 to 3.8 per cent [10]. Silicon concentration in banana roots is able to induce silicate dissolution thereby releasing silicon availability in the rhizosphere [8]. Henriet et al. (2006) [7] reported Si concentration and uptake in banana increased with silica supply. The plants are known to produce phytoliths (discrete silicon deposits) in the leaves and pseudostem, which persist in the soil long after plant death, leading to their use in archaeological studies to track the cultivation and consumption of banana [13]. When silicon is present in the soil solution at high concentrations, banana plants absorb it passively but switch to active uptake via theoretical transporters when concentrations are low [6]. Banana plants have been used as a model to study biogeochemical silicon cycling by comparing 28Si and 29Si isotope absorption [23].

\subsection{Location of study}

\section{MATERIALS AND METHODS}

The field experiments were conducted in the farmer's holding located at Rajagopalapuram village under Kuttalam taluk, Mayiladuthurai district, Tamilnadu, India. The experimental field is geographically situated $11.10^{\circ} \mathrm{N}$ and $79.67^{\circ} \mathrm{E}$ at an altitude of $16 \mathrm{~m}$ above mean sea level.

\subsection{Experimental soil}

The experimental soil is sandy clay loam in texture belongs to Padugai series (Typic Ustifluvent) with soil pH- 7.39, EC- $0.24 \mathrm{dSm}^{-1}$, soil organic carbon- $3.5 \mathrm{~g} \mathrm{~kg}^{-1}, \mathrm{KMnO}_{4}-\mathrm{N}-260 \mathrm{kgha}^{-1}$ ( low), Olsen-P- $20.2 \mathrm{kgha}^{-1}$ (high), NH $4 \mathrm{OAc}-\mathrm{K}($ $251 \mathrm{~kg} \mathrm{ha}^{-1}$ ( medium) and available silicon $-29 \mathrm{mg} \mathrm{kg}^{-1}$ ( low)

\subsection{Treatment structure and design}

The experiment for banana was laid out in randomized block design with ten treatments in three replications. The treatment consists of $\mathrm{T}_{1}-\mathrm{NPK}(\mathrm{RDF}), \mathrm{T}_{2}-\mathrm{NPK}+$ Potassium silicate (FS) $-0.25 \%, \mathrm{~T}_{3}-\mathrm{NPK}+$ Potassium silicate (FS) $0.50 \%, \mathrm{~T}_{4}-\mathrm{NPK}+$ Potassium silicate (FS) $-1.00 \%, \mathrm{~T}_{5}-\mathrm{NPK}+$ Potassium silicate (FS) $-0.25 \%, \mathrm{~T}_{6}-\mathrm{NPK}+\mathrm{Potassium}$ silicate (FS) $-0.50 \%, \mathrm{~T}_{7}-\mathrm{NPK}+$ Potassium silicate $(\mathrm{FS})-1.00 \%, \mathrm{~T}_{8}-\mathrm{NPK}+$ Potassium silicate $(\mathrm{SA})-50 \mathrm{~kg} \mathrm{ha}{ }^{-1}, \mathrm{~T}_{9}-$ NPK + Potassium silicate (SA) $-100 \mathrm{~kg} \mathrm{ha}^{-1}$ and $\mathrm{T}_{10}-\mathrm{NPK}+$ Potassium silicate (SA) $-150 \mathrm{~kg} \mathrm{ha} \mathrm{k}^{-1}$. From $\mathrm{T}_{2}$ to $\mathrm{T}_{4}$ foliar spray was done at $3^{\text {rd }}$ and $5^{\text {th }}$ month and from $\mathrm{T}_{5}$ to $\mathrm{T}_{7}$, foliar spray was done at $3^{\text {rd }}, 5^{\text {th }}$ and $7^{\text {th }}$ month. The test crop is Banana Var. Grand Naine.

\subsection{Crop husbandry}

The experimental field was thoroughly ploughed to a fine tilth and levelled. After levelling, the plots were laid out as per the specific plot size of $3 \times 4 \mathrm{~m}^{2}$. Pits of $45 \mathrm{~cm}^{3}$ size were dug at a spacing of $1.8 \times 1.8 \mathrm{~m}$. The pits were filled with top soil and $40 \mathrm{~g}$ of Furadon granules was applied to each pit prior to planting. Uniform sized tissue cultured plant of G9 of 3 months old obtained from Kodeeswaran Biotech, Hosur, was planted in pits. Recommended cultural practices were carried out regularly and uniformly for all the treatments. Following is the fertilizers dosage for tissue culture banana, which was applied uniformly to all the plots. Silicon treatment was superimposed over RDF and was applied through potassium silicate. $\left(22 \% \mathrm{Si}, \mathrm{K}_{2} \mathrm{O}-11 \%\right)$

\begin{tabular}{|c|c|c|c|}
\hline \multirow{2}{*}{ Days after planting } & \multicolumn{3}{|c|}{ Fertilizers dose $(\mathrm{g}$ plant } \\
& -1 & SSP & MOP \\
\cline { 2 - 4 } & Urea & 125 & 50 \\
\hline 30 & 45 & 125 & 85 \\
\hline 75 & 90 & 125 & 85 \\
\hline 110 & 110 & 125 & 100 \\
\hline 150 & 110 & 125 & 100 \\
\hline 180 & 90 & - & 85 \\
\hline At bunch emergence & - & & \\
\hline
\end{tabular}

Source: NRC Banana

Potassium content in potassium silicate was adjusted before potassium was applied to the field through $\mathrm{KCl}$. Cultural measures were undertaking periodically to keep the crop in good condition.

\subsection{Observations and Analysis}

The banana yield was calculated by multiplying the yield per plant with total number of plants per hectare and expressed as $\mathrm{tha}^{-1}$. The representative fingers were allowed for natural ripening and used for determining the quality parameters viz., Total soluble solids (TSS), reducing sugars, non-reducing sugar, total sugars, acidity and sugar: acid ratio. The plant samples were washed with $0.1 \mathrm{~N} \mathrm{HCl}$ and then with distilled water, air dried and oven dried at 60 to $70^{\circ} \mathrm{C}$. The plant samples were powdered in the Wiley mill and analysed for total nitrogen, total phosphorus, total potassium and total silicon. Respective nutrient uptake was computed by multiplying dry matter yield with nutrient content divided by 100 . 


\section{RESULTS AND DISCUSSION}

\subsection{Banana Yield}

Fruit yield was significantly influenced by soil and foliar application of silicon applied through potassium silicate over control (table 1). Soil application of silicon recorded higher banana yield compared to foliar application. The per cent increase in fruit yield due to silicon treatments ranged from 3.34 to 14.62 and yield response ranged from 3.8 to $12.1 \mathrm{tha}$ ${ }^{1}$ due to various silicon treatments over control. Fruit yield was maximum with $50 \mathrm{~kg} \mathrm{Si} \mathrm{ha}{ }^{-1}$ and declined with increase in silicon rate. Similarly, fruit yield also increased with silicon concentration (0.25 to $1 \%)$. Foliar spray of $1 \%$ silicon applied at $3^{\text {rd }}$ and $5^{\text {th }}$ month after planting recorded the highest fruit yield compared to 0.25 and $0.5 \%$ Si. The frequency of foliar spray influenced fruit yield. When potassium silicate was sprayed thrice $\left(3^{\text {rd }}, 5^{\text {th }}\right.$ and $7^{\text {th }}$ month $)$ at $0.25 \%$ and $0.5 \%$, fruit yield increased but at $1 \% \mathrm{Si}$ fruit yield decreased. Increase in the productivity could be attributed to the beneficial effect of silicon in the plant as an improvement of architecture for showing more erect leaves, which intercept higher solar luminosity increasing the photosynthesis efficiency and higher chlorophyll content. Silicon increased the photosynthetic efficiency of the plant resulting in greater accumulation of solids in the leaf tissues. These photo assimilates can be translocated to the fruits which are strong metabolic drains. It may be one of the factors, which increased the productivity. Fiori (2006)[6] reported increase in fruit yield is due to increase in fruit number and size of fruit which are attributed to increase in availability of silicon in soil. Higher fruit yield could also be due to better availability of nutrients in the soil for increased uptake, which led to higher growth and fruit yield. Role of silicon in augmenting higher banana yield was further strengthened by regression analysis (Fig. 1), it showed that 86.0 per cent, 82.3 per cent and 85.3 per cent variation in banana yield was due to available silicon, silicon content and uptake respectively. Ahmed et al. (2013) [1] reported higher fruit yield of Date palm on application of $0.1 \%$ potassium silicate. Lalithya et al. (2014) [12] reported highest fruit yield of sapota with foliar spray of potassium silicate at $8 \mathrm{ml} \mathrm{L}^{-1}$. Marodin et al. (2014)[17] noticed maximum tomato yield at $40 \mathrm{~kg} \mathrm{Si} \mathrm{ha}{ }^{-1}$ and decreased with further increase in silicon levels. Tesfagiorgis and Lang (2013) [28] reported applications of $\mathrm{Si}$ at $50 \mathrm{mg} \mathrm{L}^{-1}$ resulted in maximum growth of Zucchini and Zinnia and reduced the growth at $100 \mathrm{mg} \mathrm{Si}$ $\mathrm{L}^{-1}$.

Table 1. Effect of Potassium Silicate on Fruit yield ( $\left.\mathrm{t} \mathrm{ha}^{-1}\right)$ of Banana var Grand Naine

\begin{tabular}{|c|c|c|c|}
\hline Treatments & $\begin{array}{l}\text { Fruit yield } \\
\left(\text { tha }^{-1}\right)\end{array}$ & $\begin{array}{c}\text { Per cent increase } \\
\text { over control }\end{array}$ & $\begin{array}{c}\text { Fruit yield } \\
\text { response }\left(\mathrm{t} \mathrm{ha}^{-1}\right)\end{array}$ \\
\hline $\mathrm{T}_{1}-\mathrm{RDF}$ (Control) & 83.9 & - & -- \\
\hline $\mathrm{T}_{2}-\mathrm{RDF}+\mathrm{PS}(\mathrm{FS})-0.25 \% @ 3^{\mathrm{rd}} \& 5^{\mathrm{th}}$ month & 86.8 & 3.34 & 3.8 \\
\hline $\mathrm{T}_{3}-\mathrm{RDF}+\mathrm{PS}(\mathrm{FS})-0.50 \% @ 3^{\text {rd }} \& 5^{\text {th }}$ month & 89.4 & 6.56 & 5.8 \\
\hline $\mathrm{T}_{4}-\mathrm{RDF}+\mathrm{PS}(\mathrm{FS})-1.0 \% @ 3^{\text {rd }} \& 5^{\text {th }}$ month & 92.7 & 10.49 & 6.8 \\
\hline $\mathrm{T}_{5}-\mathrm{RDF}+\mathrm{PS}(\mathrm{FS})-0.25 \% @ 3^{\text {rd }}, 5^{\text {th }} \& 7^{\text {th }}$ month & 88.4 & 5.36 & 5.4 \\
\hline $\mathrm{T}_{6}-\mathrm{RDF}+\mathrm{PS}(\mathrm{FS})-0.5 \% @ 3^{\text {rd }}, 5^{\text {th }} \& 7^{\text {th }}$ month & 91.5 & 9.06 & 7.6 \\
\hline $\mathrm{T}_{7}-\mathrm{RDF}+\mathrm{PS}(\mathrm{FS})-1.0 \% @ 3^{\mathrm{rd}}, 5^{\text {th }} \& 7^{\text {th }}$ month & 90.9 & 8.34 & 7.0 \\
\hline $\mathrm{T}_{8}-\mathrm{RDF}+\mathrm{PS}(\mathrm{SA})-50 \mathrm{~kg} \mathrm{ha}^{-1}$ & 96.0 & 14.42 & 12.1 \\
\hline $\mathrm{T}_{9}-\mathrm{RDF}+\mathrm{PS}(\mathrm{SA})-100 \mathrm{~kg} \mathrm{ha}^{-1}$ & 94.1 & 12.2 & 10.2 \\
\hline $\mathrm{T}_{10}-\mathrm{RDF}+\mathrm{PS}(\mathrm{SA})-150 \mathrm{~kg} \mathrm{ha}^{-1}$ & 92.3 & 10.2 & 8.4 \\
\hline $\mathrm{SE}_{\mathrm{d}}$ & 1.82 & 0.19 & 0.12 \\
\hline CD@ @ $5 \%$ & 3.64 & 0.41 & 0.26 \\
\hline
\end{tabular}




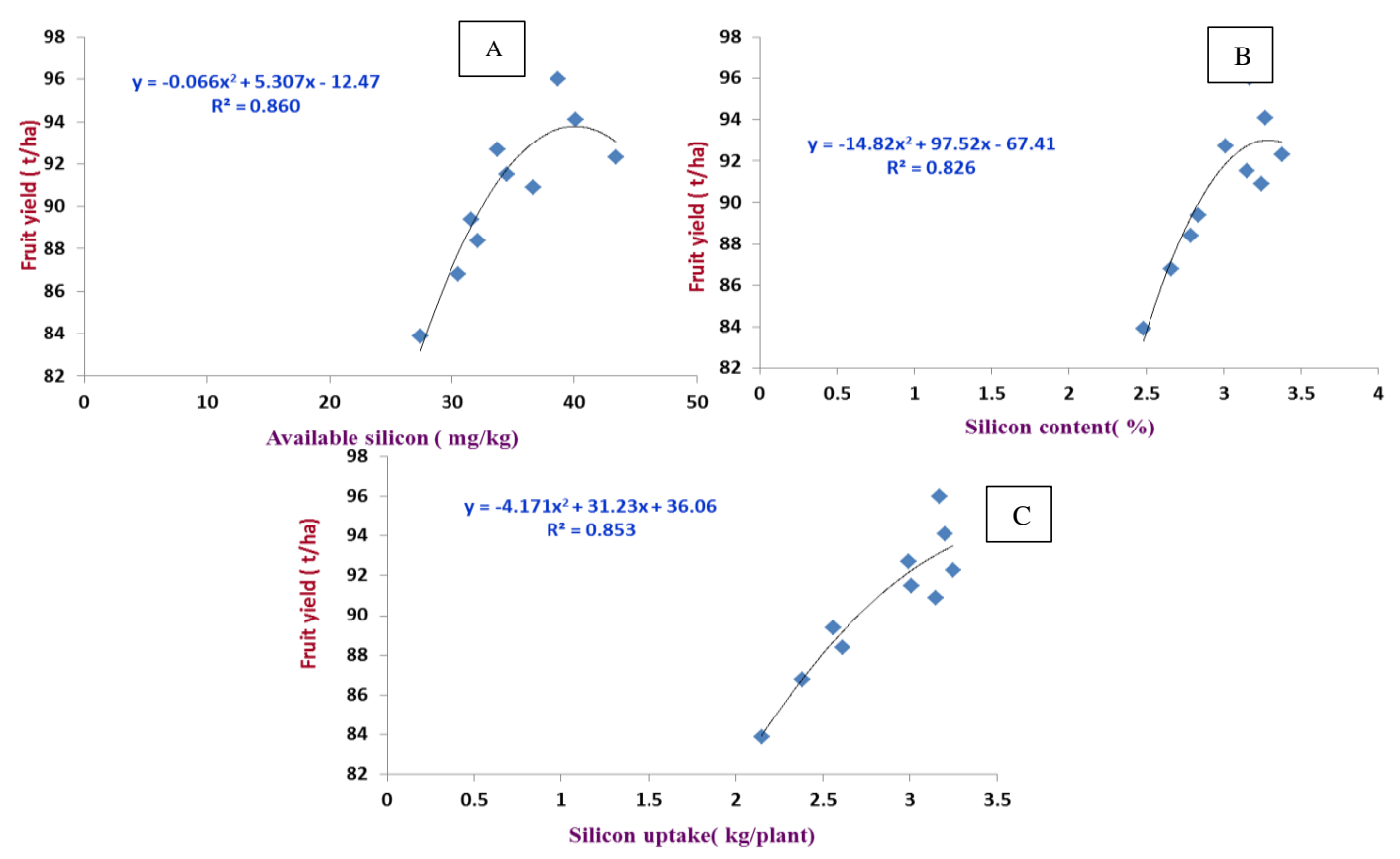

Fig.1. Quadratic relationship between fruit yield with a) available silicon b) silicon content C) Silicon uptake

\subsection{Banana Nutrition}

Cursory glance at the fig 3 revealed marked influence of silicon applied through soil and foliar on uptake of nutrients by banana over control. Soil application of silicon recorded higher nutrient uptake over foliar addition. The nutrient uptake increased with Si levels and maximum content and uptake was noticed with $150 \mathrm{~kg} \mathrm{Si} \mathrm{ha}^{-1}$. (table 2) With respect to foliar treatments, nutrient uptake increased with concentrations $(0.25$ to $1.0 \%)$ and the highest uptake was noticed with foliar spray of $1 \% \mathrm{Si}$ applied at $3^{\text {rd }}$ and $5^{\text {th }}$ month. Soil application of silicon recorded higher nutrient uptake compared to foliar nutrition. Per cent increase in nutrient uptake by silicon treatment over control (Fig. 2) showed marked influence of silicon Soil treatment with biogeochemically active $\mathrm{Si}$ sources optimizes fertility through improved water, physical and chemical soil properties and maintenance of nutrients in plant available form [16]. This could be reason for higher nutrient content and uptake in banana plant. Silicon is taken by plant mainly as uncharged orthosilicic acid [14]. Nevertheless root fertilization with silicon significantly affected the uptake and distribution of nutrients in plants [3]. Secondly silicon application improves photosynthetic activity that improves the supply of carbohydrates which in turn increased root activity, root oxidation power and promotes water and nutrient uptake. Ahmed et al. (2013)[1] reported increase in leaf N, $\mathrm{P}, \mathrm{K}$ and Si content in date palm on foliar application of $0.1 \%$ potassium silicate. Aziz et al. (2002)[3] reported beneficial effect of silicon fertilization in improving phosphorus nutrition of plants. Silicon application avoided leaching loss of $\mathrm{N}$ and helped in more accumulation of $\mathrm{N}$ in leaf. Similarly, silicon rendered more $\mathrm{P}$ available to the plants reversing its fixation as silicon itself competed for $\mathrm{P}$ fixation and thus slowly released $\mathrm{P}$ helped in more accumulation of $\mathrm{P}$ content in leaf. Potassium silicate application either soil or foliar recorded higher $\mathrm{K}$ concentration because it contained potassium along with silicon. Higher availability of silicon in the soil solution paved way for the better translocation of silicon from the root to shoot. Similarly, foliar spray of silicon to the foliage caused improved translocation of Si to the leaf and other parts and coupled with higher leaf dry weight. Increase in silicon content and uptake was noticed in the present study. Lalithya et al. (2014)[12] reported foliar spray of potassium silicate at $8 \mathrm{ml} / \mathrm{l}$ recorded higher $\mathrm{N}, \mathrm{P}, \mathrm{K}$ and $\mathrm{Si}$ content in sapota. The results are in conformity with finding of [29] in citrus, [11] in Zinnia, [21] in bean, [20]in Lettuce and [26] in banana. 
Table 2. Effect of Potassium Silicate on Nutrient Uptake (g plant ${ }^{-1}$ ) of Banana var Grand Naine

\begin{tabular}{|c|c|c|c|c|}
\hline Treatments & Nitrogen & Phosphorus & Potassium & Silicon \\
\hline $\mathrm{T}_{1}-\mathrm{RDF}$ (Control) & 807.7 & 234.5 & 1928.1 & 2153.9 \\
\hline $\mathrm{T}_{2}-\mathrm{RDF}+\mathrm{PS}(\mathrm{FS})-0.25 \% @ 3^{\mathrm{rd}} \& 5^{\text {th }}$ month & 1039.4 & 268.5 & 2437.1 & 2383.4 \\
\hline $\mathrm{T}_{3}-\mathrm{RDF}+\mathrm{PS}(\mathrm{FS})-0.50 \% @ 3^{\text {rd }} \& 5^{\text {th }}$ month & 1107.0 & 297.2 & 2800.6 & 2557.4 \\
\hline $\mathrm{T}_{4}-\mathrm{RDF}+\mathrm{PS}(\mathrm{FS})-1.0 \% @ 3^{\text {rd }} \& 5^{\text {th }}$ month & 1316.3 & 346.4 & 3483.7 & 2978.9 \\
\hline $\mathrm{T}_{5}-\mathrm{RDF}+\mathrm{PS}(\mathrm{FS})-0.25 \% @ 3^{\text {rd }}, 5^{\text {th }} \& 7^{\text {th }}$ month & 1128.4 & 307.8 & 2807.1 & 2601.9 \\
\hline $\mathrm{T}_{6}-\mathrm{RDF}+\mathrm{PS}(\mathrm{FS})-0.5 \% @ 3^{\text {rd }}, 5^{\text {th }} \& 7^{\text {th }}$ month & 1253.3 & 344.4 & 3424.9 & 3013.6 \\
\hline $\mathrm{T}_{7}-\mathrm{RDF}+\mathrm{PS}(\mathrm{FS})-1.0 \% @ 3^{\text {rd }}, 5^{\text {th }} \& 7^{\text {th }}$ month & 1365.2 & 358.2 & 3592.0 & 3146.7 \\
\hline $\mathrm{T}_{8}-\mathrm{RDF}+\mathrm{PS}(\mathrm{SA})-50 \mathrm{~kg} \mathrm{ha}^{-1}$ & 1530.3 & 340.1 & 3570.7 & 3170.6 \\
\hline $\mathrm{T}_{9}-\mathrm{RDF}+\mathrm{PS}(\mathrm{SA})-100 \mathrm{~kg} \mathrm{ha}^{-1}$ & 1567.4 & 352.7 & 3678.5 & 3203.3 \\
\hline $\mathrm{T}_{10}-\mathrm{RDF}+\mathrm{PS}(\mathrm{SA})-150 \mathrm{~kg} \mathrm{ha}^{-1}$ & 1604.2 & 374.6 & 3756.3 & 3246.8 \\
\hline $\mathrm{SE}_{\mathrm{d}}$ & 33.35 & 15.31 & 70.39 & 137.14 \\
\hline CD@ $9 \%$ & 70.07 & 32.17 & 147.90 & 288.13 \\
\hline
\end{tabular}

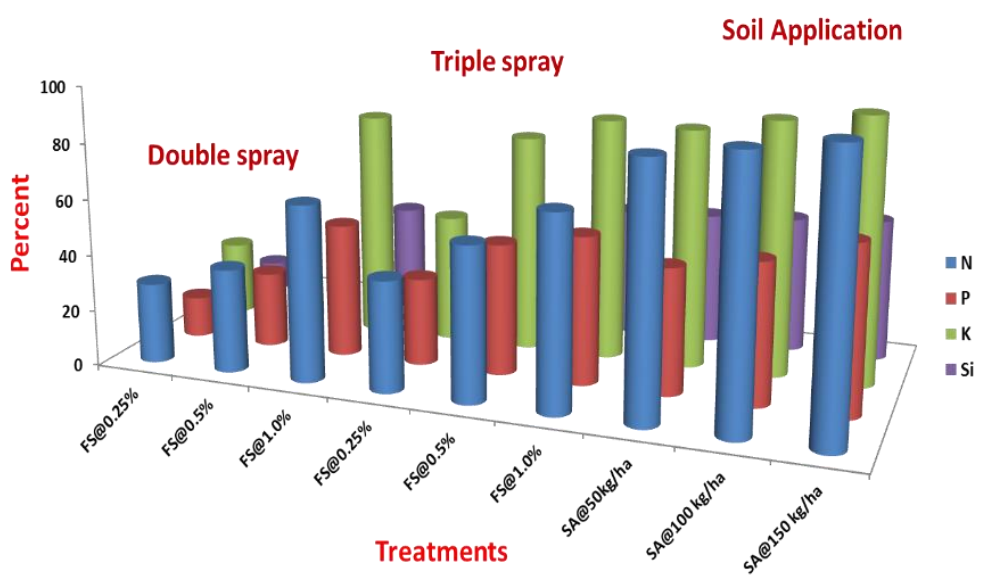

Fig 2. Percent increase in nutrient uptake by banana leaf due to silicon over control
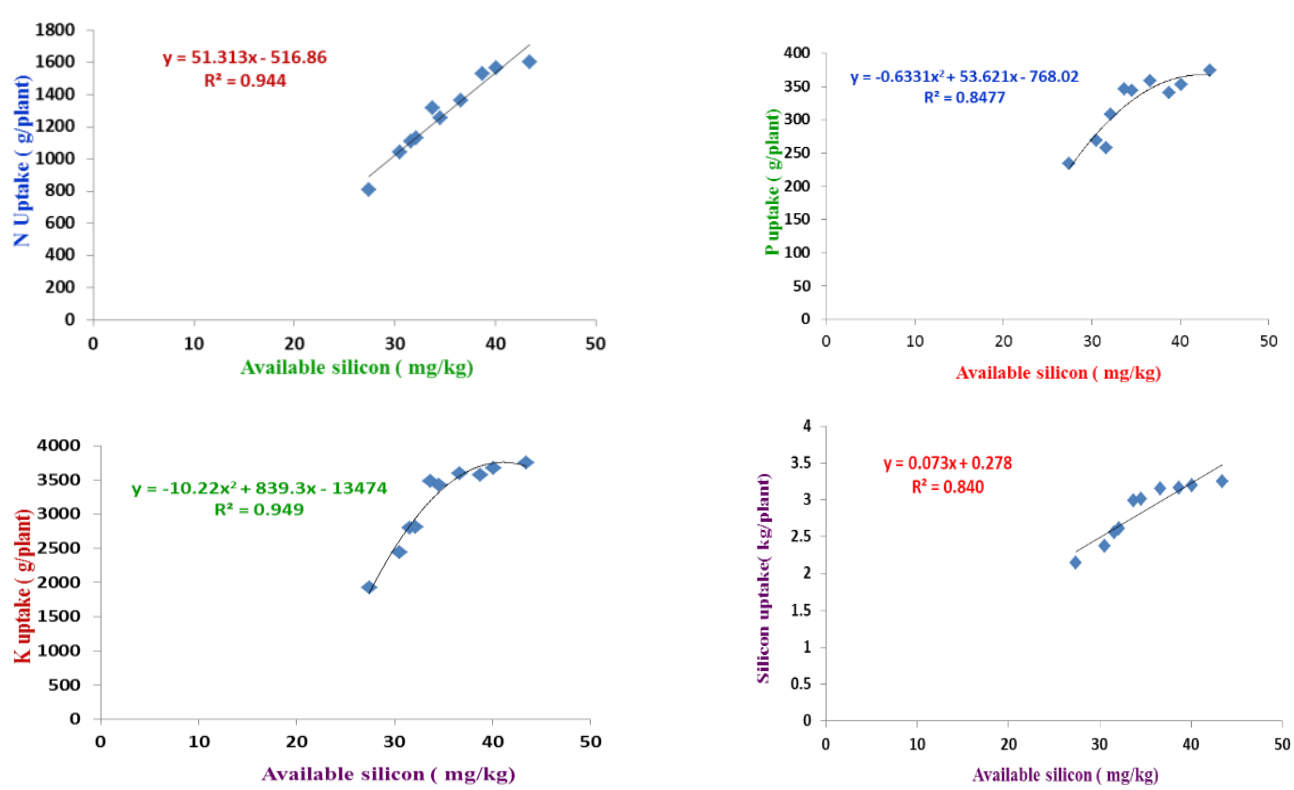

Fig.3 Quadratic relationship between available silicon with N, P and K uptake and linear relationship with Si uptake

\subsection{Fruit Quality}

Addition of silicon through soil and foliar significantly improved various fruit quality parameters viz., TSS, acidity, total sugar, non-reducing sugar and reducing sugar, leaf protein and pulp-peel ratio over control ( table 3). Soil application 
of silicon improved the fruit quality over foliar application. Soil application of $50 \mathrm{~kg} \mathrm{Si} \mathrm{ha-1} \mathrm{recorded} \mathrm{the} \mathrm{highest} \mathrm{fruit}$ quality viz., TSS, total sugars, reducing and non-reducing sugar and leaf protein and it declined with Si levels. Acidity decreased with silicon addition. With respect to foliar treatments, fruit quality increased with concentrations $(0.25$ to $1.0 \%)$ and the highest fruit quality was noticed with foliar spray of $1 \% \mathrm{Si}$ applied at $3^{\text {rd }}$ and $5^{\text {th }}$ month. Foliar spray of 0.25 and $0.5 \% \mathrm{Si}$ applied thrice increased the fruit quality compared to twice application at same concentration. But fruit quality declined when Si was sprayed at $1 \%$ thrice. Optimization of silicon nutrition resulted in series of positive effect of plants and one among them is improved fruit quality. Increase in fruit quality on addition of silicon is due to suppression of respiration and reduction in ethylene evolution and thus minimized physiological loss in weight of the fruit. Potassium silicate helped in the synthesis of more sugar content in fruit and this resulted in increase in TSS. Stamatakis et al. (2003) [27] reported that increase in TSS in tomato on addition of silicon. Lalithya et al. (2014) reported higher TSS in sapota on foliar spray of potassium silicate at $8 \mathrm{ml} \mathrm{L}^{-1}$. Aziz et al. (2002)[3] and Zhigniew Jarosz (2013)[30] reported higher TSS in cucumber fruit on silicon addition. Ahmed et al. (2013) [1] reported increased in TSS, reducing sugar and non-reducing sugar, acidity, total sugar in Date palm as foliar spray of potassium silicate at $0.1 \%$ They attribute increase in fruit quality on silicon addition is because of tolerance of plants to all stresses due to increase in antioxidant defence system as well as their important role in the biosynthesis of organic foods. Martichenkov and Calvert (2002)[19] also reported increased in levels of total sugar, soluble sugars, sucrose, and raffinose on addition of silicon. The regression analysis (Fig.4) showed that Si uptake accounted 67.6 per cent variation in TSS; 90.4 per cent variation in acidity; 88.4 per cent variation in nonreducing and reducing sugar, respectively.
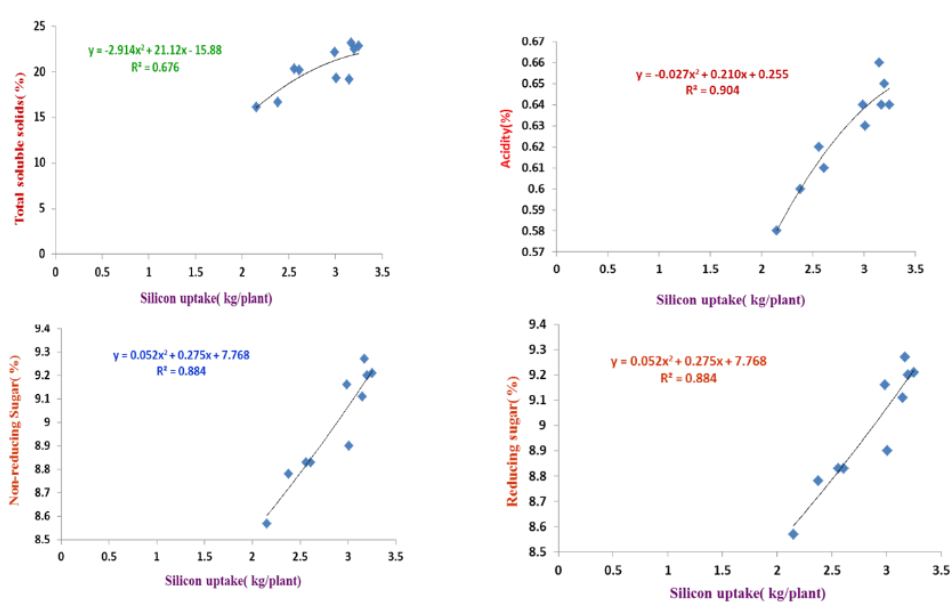

Fig.4. Quadratic relationship between silicon uptake with banana quality

Table 3. Effect of Potassium Silicate on Fruit Quality of Banana var Grand Naine

\begin{tabular}{|c|c|c|c|c|c|c|c|c|}
\hline Treatments & $\begin{array}{c}\text { TSS } \\
\text { (brix } \\
\% \text { ) }\end{array}$ & $\begin{array}{c}\text { Acidity } \\
(\%)\end{array}$ & $\begin{array}{c}\text { Total } \\
\text { sugars } \\
(\%)\end{array}$ & $\begin{array}{l}\text { Sugar: } \\
\text { acid } \\
\text { ratio }\end{array}$ & $\begin{array}{c}\text { Non- } \\
\text { reducing } \\
\text { sugar }(\%)\end{array}$ & $\begin{array}{l}\text { Reducing } \\
\text { sugar } \\
(\%)\end{array}$ & $\begin{array}{c}\text { Crude } \\
\text { protein } \\
(\%)\end{array}$ & $\begin{array}{c}\text { Pulp: } \\
\text { peel ratid }\end{array}$ \\
\hline $\mathrm{T}_{1}-\mathrm{RDF}$ (Control) & 16.16 & 0.66 & 15.78 & 27.20 & 5.71 & 8.57 & 5.81 & 2.24 \\
\hline $\mathrm{T}_{2}-\mathrm{RDF}+\mathrm{PS}(\mathrm{FS})-0.25 \% @ 3^{\text {rd }} \& 5^{\text {th }}$ month & 16.66 & 0.64 & 15.82 & 27.80 & 6.05 & 8.78 & 7.25 & 2.38 \\
\hline $\mathrm{T}_{3}-\mathrm{RDF}+\mathrm{PS}(\mathrm{FS})-0.50 \% @ 3^{\text {rd }} \& 5^{\text {th }}$ month & 20.33 & 0.63 & 16.68 & 26.90 & 6.14 & 8.83 & 7.69 & 2.70 \\
\hline $\mathrm{T}_{4}-\mathrm{RDF}+\mathrm{PS}(\mathrm{FS})-1.0 \% @ 3^{\text {rd }} \& 5^{\text {th }}$ month & 22.16 & 0.61 & 17.00 & 26.70 & 6.23 & 9.16 & 8.31 & 3.17 \\
\hline $\mathrm{T}_{5}-\mathrm{RDF}+\mathrm{PS}(\mathrm{FS})-0.25 \% @ 3^{\text {rd }}, 5^{\text {th }} \& 7^{\text {th }}$ month & 20.16 & 0.64 & 16.66 & 27.31 & 6.11 & 8.83 & 7.56 & 2.87 \\
\hline $\mathrm{T}_{6}-\mathrm{RDF}+\mathrm{PS}(\mathrm{FS})-0.5 \% @ 3^{\text {rd }}, 5^{\text {th }} \& 7^{\text {th }}$ month & 19.33 & 0.63 & 16.43 & 26.07 & 6.20 & 8.90 & 8.19 & 2.91 \\
\hline $\mathrm{T}_{7}-\mathrm{RDF}+\mathrm{PS}(\mathrm{FS})-1.0 \% @ 3^{\text {rd }}, 5^{\text {th }} \& 7^{\text {th }}$ month & 19.16 & 0.61 & 15.94 & 24.16 & 6.21 & 9.11 & 8.81 & 3.00 \\
\hline $\mathrm{T}_{8}-\mathrm{RDF}+\mathrm{PS}(\mathrm{SA})-50 \mathrm{~kg} \mathrm{ha}^{-1}$ & 23.16 & 0.58 & 16.84 & 26.30 & 6.52 & 9.27 & 9.56 & 3.49 \\
\hline $\mathrm{T}_{9}-\mathrm{RDF}+\mathrm{PS}(\mathrm{SA})-100 \mathrm{~kg} \mathrm{ha}^{-1}$ & 22.50 & 0.60 & 16.77 & 25.80 & 6.42 & 9.20 & 10.0 & 3.17 \\
\hline $\mathrm{T}_{10}-\mathrm{RDF}+\mathrm{PS}(\mathrm{SA})-150 \mathrm{~kg} \mathrm{ha}^{-1}$ & 22.83 & 0.62 & 16.63 & 25.98 & 6.28 & 9.21 & 10.44 & 3.12 \\
\hline $\mathrm{SE}_{\mathrm{d}}$ & 0.45 & 0.01 & 0.32 & 1.38 & 0.12 & 0.14 & 0.19 & 0.07 \\
\hline CD@5\% & 0.94 & 0.02 & 0.67 & 2.91 & 0.26 & 0.30 & 0.41 & 0.15 \\
\hline
\end{tabular}




\section{REFERENCES}

[1] Ahmed, F.F.; Gad El- Kareem, M.R. and Oraby- Mona, M.M. (2013): Response of Zaghloul date palms to spraying boron, silicon and glutathione. Stem Cell 4(2): 29-34.

[2] Al-Aghabary, K., Zhu, Z and Q.H. Shi. 2004. Influence of silicon supply on chlorophyll content, chlorophyll fluorescence and antioxidative enzyme activities in tomato plants under salt stress. J. Plant Nutr. 27: 2101-2115.

[3] Aziz, T., Gill, M.A. and Rahmatullah, R. 2002. Silicon nutrition and crop production: A Review. Pak. J. Agric. Sci., 39(3): 181-187.

[4] Brunings, A.M., Datnoff, L.E., Ma, J.F., Mitani, N., Nagamura Y., Rathinasabapathi, B., and Kirst. M. 2009. Different gene expression of rice in response to silicon and rice blast fungus Magnaparthe oryzae. Ann. Appl. Biol., 155: 161170.

[5] Epstein, E. 1999. Silicon. Annu. Rev. Plant Physiol. Plant Mol. Biol., 50: 641-664

[6] Fiori, M.P. 2006. Comportamento de cultivares de tomateiro quanto à utilização de escórias siderúrgicas em ambiente protegido. 54. (Tese doutorado)

[7] Henriet, C., Draye, X., Oppitz, I., Swennen, R., and Delvaux, B. 2006. Effects, distribution and uptake of silicon in banana (Musa spp.) under controlled conditions. Pl. Sci., 287: 359-374.

[8] Hinsinger, P., Barros, O.N.F., Benedetti, M.F and Janeiro. 2001. Plant-induced weathering of a basaltic rock: Experimental evidence. Geochim. Cosmochim Acta, 65: 137-152

[9] Hudson, M.J., White, P.J., Mead, A., and Broadly, B.R. 2005. Phylogenetic variation in the silicon composition of plants. Ann. Bot., 96: 1027-1046.

[10] Jauhari, O.S., Mishra, R.A., Tewari C.B. 1974. Nutrient uptake of banana (Musa paradisiaca) var. Basrai Dwarf. Indian J Agric. Chem. 7:73-79

[11] Kamenidou, S., Canvins, T.J., and Marker, S. 2009. Evaluation of silicon as a nutritional supplement for greenhouse zinnia production. Scientia Hort., 119(3): 297-301

[12] Lalithya, K.A., Bhagya, H.P. and Raveendra Choudhary. 2014. Response of silicon and micronutrients on fruit character and nutrient content in leaf of sapota. Biolife, 2(2): 593-598.

[13]Lentfer, C.J. 2009. Tracing domestication and cultivation of bananas from phytoliths: An update from Papua New Guinea. Ethnobotany Research and Applications, 7: 247-270

[14]Ma, J.F. and Takahashi. E. 2002. Soil fertilizers and plant silicon research in Japan, Elsevier Science, Amsterdam, The Netherlands.

[15]Ma, J.F. and Yamaji. N. 2006. Silicon uptake and accumulation in higher plants. Trends in Plant Sci., 11(8): 342-397.

[16]Ma, J.F., Miyake, Y. and Takahashi, E. 2001. Silicon as a beneficial element for crop plants. In: Datnoff,C.E., G.H. Snyder and G.H. Korndofer. Silicon in agriculture. Elsevier Science, The Netherlands. pp. 17-35.

[17]Marodin, J.C., Resende, J.C.T., Morales, R.G.F., Silva, M.L.S., Galvao, A.G. and Zanin, D.S. 2014. Yield of tomato fruits in relation to silicon sources and rates. Horticultura Brasileira, 32: 220-224

[18]Marschner, H. 1995. Mineral nutrition of higher plants, Academic Press, London, pp. 352-357.

[19]Martichenkov, V.V. and Calvert. D.V. 2002. Prospective of silicon fertilization for citrus in Florida. Proc. Soil and Crop Sci. Soc. of Florida, 5: 137-141.

[20]Milne, C.J.I., Laubscher, C.P.I. and Ndakidemi, P.A. 2012. The alleviation of salinity include stress with applications of silicon in soilless grown (Lactuca sativa L.). Eish. International J. Physical Sci., 7(5): 735-742.

[21]Nesreen, H., Abou-Baker, M., Abdeladl M. Mohsen and Abbas. 2011. Use of silicate and different cultivation practices in alleviating salt stress on Bean plants. Australia J. Basic and Appl. Sci., 5(9): 769-781.

[22]NHB Data Base 2011. Horticultural Data Base, 2011.National Hort. Board, Gurgaon, India

[23]Opfergelt, S., Cardinal, D., Henriet, C., Draye, X., André, L. and Delvaux B. 2006. Silicon isotopic fractionation by banana (Musa spp.) grown in a continuous nutrient flow device. Plant Soil, 285: 333-345

[24]Pereira, H.S., Vitti, G.C. and Korndorfer, G.H. 2003. Comportamento de differentes fontes de silicon no solo e ha cultura do tomateiro. Revista Brasileira de ciencia de solo, 27: 101-108.

[25]Regina, D. and Katarzyna, W. 2011. The effect of silicon foliar application on the development of seasonal ornamental plants. Acta Agrobotanica, 64(4): 99-106.

[26]Roshdy, K.H.A. 2014. Effect of spraying silicon and seaweed extract on growth and fruiting of GrandNaine banana. Egypt. J. Res., 92(3): 979-991.

[27]Stamatakis, A., Papandantonakis, N., Lydakis-Simantiris, N., Kefalas, P. and Savvas. D. 2003. Effects of silicon and salinity on fruit yield quality of tomato grown hydroponically. Acta. Hort., 609: 141.

[28]Testagiorgis, H.B. and Laing. M.D. 2013. The effect of silicon level in nutrient solution on the uptake and distribution of silicon in Zucchini and Zinnia, and its interaction with the uptake of selected elements. Afr. J. Biotech., 12(14): 1617-1623.

[29]Vladimir, M., Bocharnikova, E. and Calvert, D. 2001. Response of citrus to silicon soil amendments. Proc. Fla. State Hort. Soc., 114: 94-97.

[30]Zhigniew Jarosz. 2013. The effect of silicon application and type of substrate on yield and chemical composition of leaves and fruit of cucumber. J. Elem., 403-414 
Asian Journal of Agriculture and Food Sciences (ISSN: 2321 - 1571)

Volume 9 - Issue 3, June 2021 